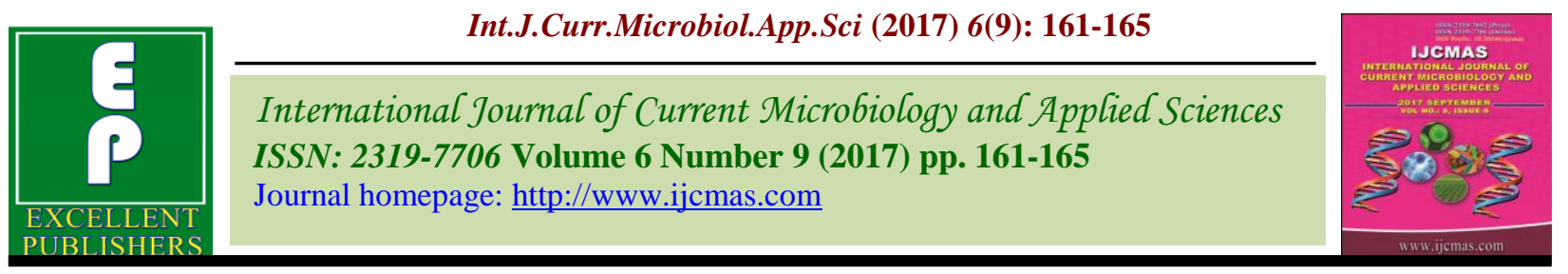

Original Research Article

https://doi.org/10.20546/ijcmas.2017.609.020

\title{
Quantification of Minimum Inoculum Level and Reaction of Ruling Chickpea Genotypes to Wilt Complex Pathogens
}

\author{
S. Ravichandran and Yashoda R. Hegde* \\ Department of Plant Pathology, University of Agricultural Sciences, \\ Dharwad-580005, Karnataka, India \\ *Corresponding author
}

A B S T R A C T

\begin{tabular}{|c|c|}
\hline & \multirow{4}{*}{$\begin{array}{l}\text { Wilt complex of chickpea is caused by Fusarium oxysporum ciceri, } \\
\text { Rhizoctonia bataticola and Sclerotium rolfsii. Minimum inoculum levels } \\
\text { required for causing } 100 \text { per cent wilt in } F \text {. oxysporum ciceri was } 8 \text { per cent } \\
R \text {. bataticola was } 10 \text { per cent and S. rolfsii was } 4 \text { per cent. Among } \\
\text { genotypes, Annigeri } 1 \text {, BGD 103, BGD } 128 \text { and KAK } 2 \text { were susceptible to } \\
\text { all the pathogens, JG11 and JAKI } 9218 \text { were showing moderately resistant } \\
\text { reaction to F. oxysporum ciceri and susceptible to other pathogens like } R \text {. } \\
\text { bataticola and S. rolfsii. }\end{array}$} \\
\hline $\begin{array}{l}\text { Wilt complex, } \\
\text { Inoculum level, } \\
\text { Genotypes, } \\
\text { Chickpea. }\end{array}$ & \\
\hline Article Info & \\
\hline $\begin{array}{l}\text { Accepted: } \\
\text { 04 July } 2017 \\
\text { Available Online: } \\
\text { 10 September } 2017\end{array}$ & \\
\hline
\end{tabular}

Introduction

Chickpea (Cicer arietinum L), also known as Gram or Bengal gram, a self-pollinating diploid is the third most important pulse crop after bean and garden peas. It belongs to the family Fabaceae. Chickpea wilt is a serious disease, which is mostly prevalent in dry weather conditions. It causes significant yield losses in different chickpea areas depending upon its prevalence and intensity.

Occurrence of chickpea wilt has been reported almost all over the world but it was first described in India (Butler, 1918). Dry root rot caused by Macrophomina phaseolina (Tassi) Goid. is one of the major limitations in chickpea production causing 10 to $20 \%$ annual loss (Dhar and Chaudhary, 2001).
Soilborne diseases like wilt caused by $F$. oxysporum f.sp. ciceri, root rot caused by Rhizoctonia bataticola and collar rot caused by Sclerotium rolfsii are becoming severe in recent years resulting in huge loss. During survey, mixed infection of theses pathogens in different combinations was observed resulting in wilt complex (Ravichandran, 2015).

Wilt resistant varieties were showing the susceptible reaction to wilt complex resulting in wilting symptoms. Hence an attempt was made to understand the reaction of ruling varieties to wilt complex pathogens in different combinations and to standardize the inoculum dose required for causing the symptoms. 


\section{Material and Methods}

\section{Standardization of inoculum density}

Giant culture of $F$. oxysporum f. sp. ciceri, Rhizoctonia bataticola and Sclerotium rolfsii was prepared for standardization of inoculum as explained below. Sand and corn meal (90:10) was used as substrate for giant culture preparation in conical flask and sterilized alternatively for two consecutive days. Fresh culture of seven days old $F$. oxysporum f. sp. ciceri of $5 \mathrm{~mm}$ disc was inoculated to flask and incubated for 20 days for full growth of the fungus, during incubation the culture was mixed thoroughly to get uniform growth. After full growth, it was used for further studies. The same procedure was used for Rhizoctonia bataticola and Sclerotium rolfsii.

The giant culture was inoculated to each pot with $400 \mathrm{~g}$ soil holding capacity. The inoculum was added at the rate of 2, 4, 6, 8, 10 and 12 per cent inoculum density. Five seeds of JG 11 variety were sown in each pot. Healthy plant without adding inoculum was maintained as control. This was followed for three pathogens viz., Fusarium oxysporum ciceri, Rhizoctonia bataticola and Sclerotium rolfsii. Four replications were maintained for each treatment. Observation on per cent disease incidence was recorded.

Reaction of chickpea genotypes to wilt complex pathogens

Pot culture study was conducted to know the reaction of popularly grown chickpea genotypes to wilt complex pathogens viz., Fusarium oxysporum f. sp ciceri, Rhizoctonia bataticola and Sclerotium rolfsii. The details of the experimentation are presented hereunder.

The pathogens were inoculated individually and in combination to the ruling six chickpea varities viz., Annigeri 1, JG11, JAKI 9218,
BG-103, KAK-2 and BGD 128. Three replications were maintained for each treatment. The observations were recorded at different time intervals on per cent disease incidence and analysed statistically.

\section{Results and Discussion}

\section{Standardization of inoculum density}

The results presented in table 1 indicate that the inoculum density of $F$. oxysporum ciceri at different levels influenced the development of wilt. Per cent disease incidence increased as the inoculum concentration increased. At 8 , 10 , and 12 per cent of inoculum, there was cent per cent disease incidence and death of the plants was noticed. Seed germination was completely inhibited at more than 12 per cent.

Rhizoctonia bataticola was inoculated at different concentrations. The wilt incidence was minimum at $2 \%$ and increased as the inoculum concentration increased. At 10 and 12 per cent of inoculum, there was cent per cent disease incidence and death of the plants was noticed. Seed germination was inhibited at more than 12 per cent (Table 1).

Wilt incidence differed significantly at different concentrations of Sclerotium rolfsii. Wilt was completely absent at $0 \%$ concentration and increased as the inoculum concentration increased. Complete death $(100 \%)$ of plants was recorded at 4 and $6 \%$ concentration. Inoculum at more than 6 per cent concentration inhibited the seed germination completely. Similar results were observed by (Rani and Yashoda, 2016) in Fusarium oxysporum infecting fenugreek. Hundred per cent inhibition was observed above 8 per cent inoculum in Rhizoctonia bataticola and 6 per cent in Sclerotium rolfsii infecting Coleus forskholii (Ammajamma and Yashoda, 2009), stevia (Shwetha and Yashoda, 2012) and patchouli (Chavan et al., 2009). 
Reaction of chickpea genotypes to wilt complex pathogens

\begin{tabular}{|c|l|l|}
\hline Tr. no. & \multicolumn{1}{|c|}{ Treatments } & Per cent inoculum \\
\hline 1 & Fusarium oxysporum f. sp. ciceri & 8 \\
\hline 2 & Rhizoctonia bataticola & 10 \\
\hline 3 & Sclerotium rolfsii & 4 \\
\hline 4 & F. o. ciceri + R. bataticola & $4+5$ \\
\hline 5 & F. o. ciceri + S. rolfsii & $4+2$ \\
\hline 6 & R. bataticola + S. rolfsii & $5+2$ \\
\hline 7 & F. o. ciceri + R. bataticola + S. rolfsii & $4+4+2$ \\
\hline 8 & Untreated & 0 \\
\hline
\end{tabular}

Table.1 Assessment of inoculum levels of Fusarium oxysporum ciceri, Rhizoctonia bataticola, and Sclerotium rolfsii

\begin{tabular}{|l|l|l|l|}
\hline \multirow{2}{*}{$\begin{array}{c}\text { Per cent } \\
\text { inoculum level }\end{array}$} & \multicolumn{3}{|c|}{ Per cent wilt incidence } \\
\cline { 2 - 4 } & \multicolumn{1}{|c|}{$\boldsymbol{F}$ oxysporum ciceri } & \multicolumn{1}{c|}{$\boldsymbol{R}$. bataticola } & \multicolumn{1}{c|}{ S. rolfsii } \\
\hline 0 & $0.0(0.00)^{*}$ & $0.0(0.00)^{*}$ & $0.00(0.00)^{*}$ \\
\hline 2 & $26.7(30.77)$ & $24.4(29.45)$ & $53.33(46.90)$ \\
\hline 4 & $44.4(41.74)$ & $46.7(43.06)$ & $100.00(89.96)$ \\
\hline 6 & $62.2(52.07)$ & $66.7(54.97)$ & $100.00(89.96)$ \\
\hline 8 & $100.00(89.96)$ & $81.1(64.23)$ & $100.00(89.96)$ \\
\hline 10 & $100.00(89.96)$ & $100.00(89.96)$ & $100.00(89.96)$ \\
\hline 12 & $100.00(89.96)$ & $100.00(89.96)$ & $100.00(89.96)$ \\
\hline 14 & $100.00(89.96)$ & $100.00(89.96)$ & $100.00(89.96)$ \\
\hline S.Em. \pm & 2.27 & 2.28 & 1.36 \\
\hline C.D. at $1 \%$ & 9.37 & 9.43 & 5.71 \\
\hline
\end{tabular}

* Arc sin transformed values

Table.2 Reaction of chickpea genotypes to wilt complex pathogens

\begin{tabular}{|c|c|c|c|c|c|c|}
\hline \multirow{2}{*}{ Treatments } & \multicolumn{6}{|c|}{ Per cent wilt incidence in genotypes } \\
\hline & JG 11 & Annigeri 1 & BGD 103 & BGD 128 & JAKI 9218 & KAK 2 \\
\hline Fusarium alone & $\begin{array}{l}12.22 \\
(3.26) *\end{array}$ & $50.00(7.12)$ & $\begin{array}{l}31.11 \\
(5.62)\end{array}$ & $\begin{array}{l}37.78 \\
(6.22)\end{array}$ & $\begin{array}{l}13.33 \\
(3.39)\end{array}$ & $24.44(5.01)$ \\
\hline Rhizoctonia alone & $\begin{array}{l}33.33 \\
(5.80)\end{array}$ & $40.00(6.40)$ & $\begin{array}{l}58.33 \\
(7.64)\end{array}$ & $\begin{array}{l}44.44 \\
(6.71)\end{array}$ & $\begin{array}{l}58.89 \\
(7.73)\end{array}$ & $20.00(4.58)$ \\
\hline Sclerotium alone & $\begin{array}{l}80.00 \\
(9.00)\end{array}$ & $82.22(9.09)$ & $\begin{array}{l}91.67 \\
(9.61)\end{array}$ & $\begin{array}{l}87.78 \\
(9.41)\end{array}$ & $\begin{array}{l}100.00 \\
(10.05)\end{array}$ & $88.89(9.44)$ \\
\hline $\begin{array}{l}\text { Fusarium+ } \\
\text { Sclerotium }\end{array}$ & \begin{tabular}{|l|}
75.56 \\
$(8.74)$ \\
\end{tabular} & $80.00(9.00)$ & $\begin{array}{l}61.67 \\
(7.89)\end{array}$ & $\begin{array}{l}68.89 \\
(8.35)\end{array}$ & $\begin{array}{l}71.11 \\
(8.48)\end{array}$ & $71.67(8.51)$ \\
\hline $\begin{array}{l}\text { Fusarium+ } \\
\text { Rhizoctonia }\end{array}$ & \begin{tabular}{|l|}
33.33 \\
$(5.80)$ \\
\end{tabular} & $46.67(6.90)$ & \begin{tabular}{|l|}
44.44 \\
$(6.69)$ \\
\end{tabular} & \begin{tabular}{|l|}
53.33 \\
$(7.34)$ \\
\end{tabular} & \begin{tabular}{|l|}
41.11 \\
$(6.47)$ \\
\end{tabular} & $51.11(7.16)$ \\
\hline $\begin{array}{l}\text { Rhizoctonia+ } \\
\text { Sclerotium }\end{array}$ & $\begin{array}{l}76.67 \\
(8.80)\end{array}$ & $73.33(8.60)$ & $\begin{array}{l}86.67 \\
(9.35)\end{array}$ & $\begin{array}{l}70.00 \\
(8.38)\end{array}$ & $\begin{array}{l}66.67 \\
(8.21)\end{array}$ & $82.22(9.12)$ \\
\hline $\begin{array}{l}\text { Fusarium+ } \\
\text { Rhizoctonia+ } \\
\text { Sclerotium }\end{array}$ & $\begin{array}{l}94.44 \\
(9.76)\end{array}$ & $100.00(10.05)$ & $\begin{array}{l}100.00 \\
(10.05)\end{array}$ & $\begin{array}{l}100.00 \\
(10.05)\end{array}$ & $\begin{array}{l}94.44 \\
(9.76)\end{array}$ & $82.22(9.12)$ \\
\hline Control & $\begin{array}{l}0.00 \\
(1.00)\end{array}$ & $0.00(1.00)$ & $\begin{array}{l}0.00 \\
(1.00)\end{array}$ & $0.00(1.00)$ & $0.00(1.00)$ & $0.00(1.00)$ \\
\hline S.Em & 0.53 & 0.29 & 0.45 & 0.36 & 0.50 & 0.37 \\
\hline CD@1\% & 2.20 & 1.19 & 1.85 & 1.49 & 2.05 & 1.54 \\
\hline
\end{tabular}

$* \sqrt{\mathrm{X}+1}$ transformed values 


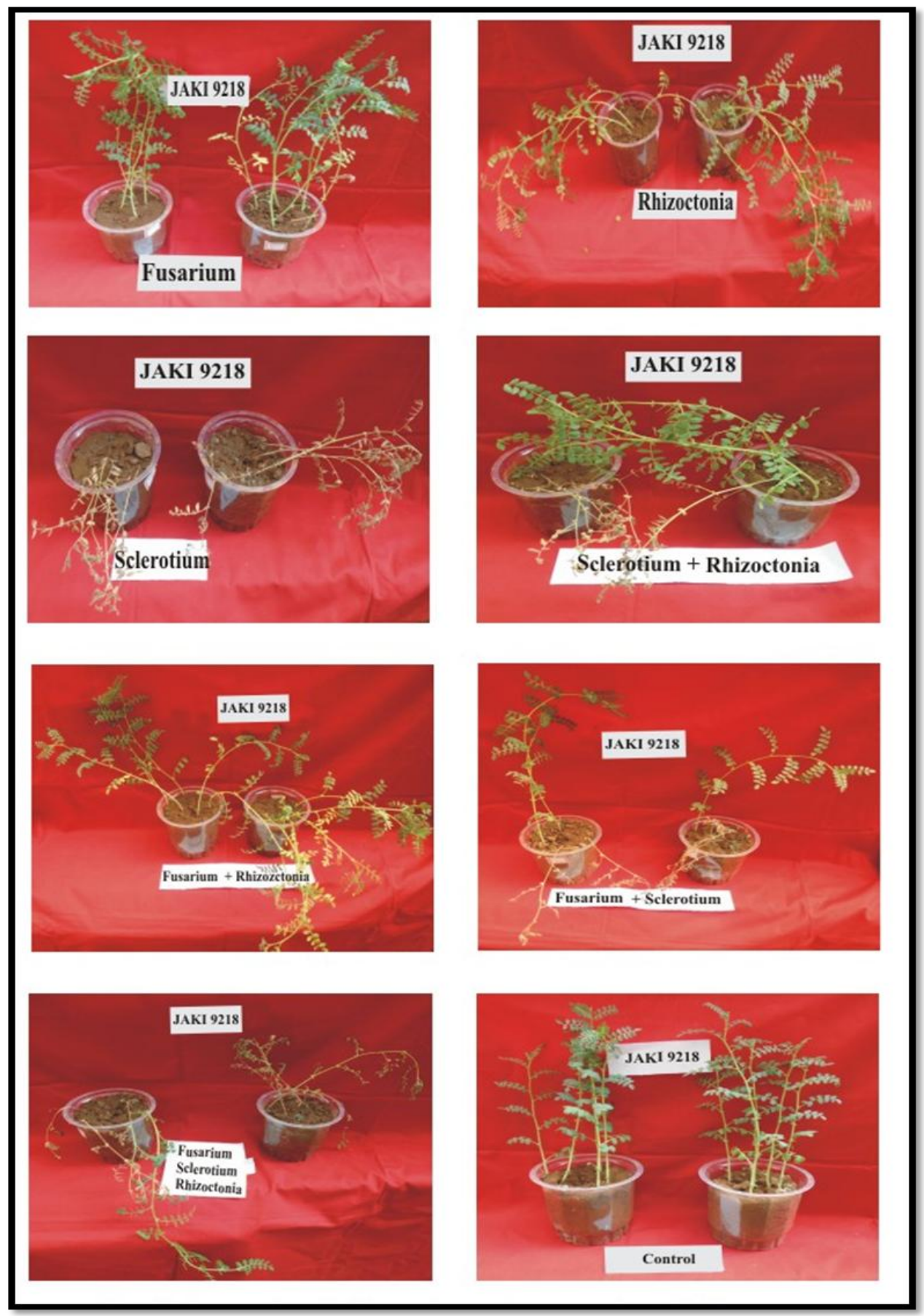

Reaction of chickpea genotypes to wilt complex pathogens

All the treatments induced wilt incidence except in control, out of six genotypes, Fusarium oxysporum ciceri resulted in maximum disease incidence $(50.0 \%)$ in Annigeri 1 genotype, lowest disease incidence was observed in JG 11 (12.22\%) followed by genotype JAKI 9218 (13.33\%). When Rhizoctonia bataticola was inoculated, maximum disease was observed in JAKI 9218 (58.89\%) followed by BGD $103(58.33 \%)$ and lowest disease incidence was observed in KAK 2 (20.0\%). In Sclerotium rolfsii inoculation, all the genotypes showed more 
disease incidence compared to other pathogens. Genotype like JAKI 9218 exhibited cent per cent wilt incidence due to S. rolfsii followed by BGD 103 (91.67\%) (Table 2 and Plate 1). In combinations of the pathogens like Fusarium + Sclerotium, all the genotypes showed more than sixty per cent wilt incidence, highest disease incidence was observed in the Annigeri $1(80.0 \%)$ followed by JG11 (75.56\%) and lowest disease was observed in BGD 103 (61.57\%). In the combined inoculation of Fusarium + Rhizoctonia, the maximum disease incidence was recorded in the BGD 128 (53.33\%) followed by $(51.11 \%)$ in KAK 2 genotype. In the combination of the pathogens like Rhizoctonia + Sclerotium the highest disease was recorded in the genotype BGD 103 $(86.67 \%)$ and all the genotypes recorded more than sixty per cent disease incidence in this combination. When all the pathogens were inoculated simultaneously (Fusarium + Rhizoctonia + Sclerotium), all the genotypes showed more than eighty per cent disease incidence, genotypes Annigeri 1, BGD 103, BGD 128 revealed cent per cent disease incidence.

JG11 genotype recorded minimum infection by Fusarium oxysporum ciceri however exhibiting susceptible reaction to $R$. bataticola and $S$. rolfsii. Same trend was observed in genotype JAKI 9218 also. Genotypes resistant to single pathogen may become susceptible to other pathogens of wilt complex. Disease incidence was more when Sclerotium rolfsii was inoculated individually or in combination with other pathogens.

\section{References}

Ammajamma, R., and Yashoda R. Hegde, 2009, Efficacy of fungicides against Rhizoctonia bataticola causing wilt of Coleus forskohlii. International Journal of Plant Protection, 2 (1): 31-32.

Butler, E. J., 1918, Fungi and Diseases of Plants, Bishen Singh Mahendra Pal Singh, New Connaugh Place., Dehradun Periodical Experts. 42-D, ivek Vihar, Delhi, 32, 547 pp.

Chavan, S. C., Hegde, Y. R. and Prashanti, S. K., 2009, Management of wilt of patchouli caused by Fusarium solani. J. Mycol. Pl. Pathol., 39(1): 32-34.

Dhar, V., and Chaudhary, R. G., 2001, Disease resistance in pulse cropcurrent status and future approaches. In: Nagarajan, S., Singh, D. P., (ed.), the role of resistance in intensive agriculture. New Delhi: Kalyani, pp. 144-157.

Rani, N., and Yashoda R. Hegde, 2016, In vitro and in vivo management of root rot/wilt of fenugreek through biological and chemical methods. Journal of pure and applied microbiology, 10(4): 2849 $-2856$.

Ravichandran, S., 2015, Studies on soilborne fungal diseases of chickpea. Ph.D. Thesis, Univ. Agric. Sci., Dharwad, Karnataka (India).

Shwetha, G.S., and Yashoda R. Hegde, 2012, Management of Sclerotium wilt of Stevia rebaudiana through biorationals. International Journal of Plant Protection, 5 (2): 248-251.

\section{How to cite this article:}

Ravichandran S. and Yashoda R. Hegde. 2017. Quantification of Minimum Inoculum Level and Reaction of Ruling Chickpea Genotypes to Wilt Complex Pathogens. Int.J.Curr.Microbiol.App.Sci. 6(9): 161-165. doi: https://doi.org/10.20546/ijcmas.2017.609.020 